\title{
Folk music for children's choirs: the challenges and benefits of cultural diversity
}

\author{
Riekie van Aswegen* and Hetta Potgieter
}

Music Division, Faculty of Education, University of Pretoria, South Africa;

School of Music, North-West University, Potchefstroom campus, South Africa

*Corresponding author: riekie.vanaswegen@up.ac.za

\begin{abstract}
In this article we investigate 'folk' music in the choral repertoire of children's choirs as a way of building bridges between diverse cultures within the context of regional children's choirs, with specific reference to the University of Pretoria Jacaranda Children's Choir, which performs under the auspices of the University of Pretoria, as a sample case study. This descriptive qualitative study investigates the challenges and benefits of including folk music in the repertoire of children's choirs in South Africa, while also taking into account the views of internationally recognised conductors of overseas children's choirs. We address challenges in preserving the authentic character of folk music in choral performances, issues regarding transcribing African folk music, copyright, and the availability of scores and audiovisual media We also investigate the extent to which folk music is included in programmes of South African children's choirs and ways in which folk music as choral repertoire can play a role in promoting the transformation process in South Africa.
\end{abstract}

\section{Introduction}

There is renewed interest in folk music ${ }^{1}$ worldwide, as folk music 'expresses the core of a culture; it evokes images, gives impressions, and touches emotions. These experiences pave the way for an acceptance of diversity and variety in human life' (Pohjola 1993:112). The increasing degree of contact between music cultures from all over the world is having an influence on the revival of folk music (Carter 2010). Nettle points out that '[t]he musics of the world are much more readily available to most people through the mass media' (1998:23). Avorgbedor argues that the rapid scientific, technological and industrial

In the literature various terms are used for 'folk music', for example, 'indigenous music', 'world music or musics.' Apel defines 'folk music' as '[t'he musical repertory and tradition of communities (particularly rural), as opposed to art music, which is the work of musically trained composers. It generally develops anonymously [...] and originally was (and may still be) transmitted aurally, thereby becoming subject to modification' (Apel 1979:323). The term 'folk music' is used in this article because of the involvement of international research participants who commonly use 'folk music' in their countries. It is used as a neutral term that does not reflect any sense in inferiority or superiority. 
progress we witness today [...] no doubt have diverse implications for all disciplines, including ethnomusicology' (1992:45). Consequently, there is an interest in folk music universally and more emphasis is being placed on the inclusion of folk music in children's choir repertoire. However, choosing folk music as part of the choral repertoire not only offers valuable benefits, but also involves certain challenges. The choice of repertoire to be prepared for public performances is considered to be one of a choir conductor's major challenges and plays an important role in the choir's performance (Lamb 2006:8; Apfelstadt 2000:19; Miller 1979:35; Pohjola 1993:194; Van Pletzen 1995:204, 231; Ashworth-Bartle 2003:182.) Ala-Pöllänen states that, as choral conductor, repertoire is a 'most important tool [...] The repertoire is the basic thing. I carry out my pedagogical aim via repertoire' (Ala-Pöllänen 2004). Gordon argues that '[i]n a sense, repertoire selection is a juggling act in which several ingredients for success are balanced' (1989:28). This article investigates the 'juggling act' when choosing folk music as choral repertoire for children's choirs, ${ }^{2}$ with specific reference to South Africa. It is against this background that the primary research question is posed: What are the challenges and benefits of including folk music in the repertoire of children's choirs in South Africa? ${ }^{3}$ The following subquestions are derived from the primary research focus:

- What are the challenges in preserving the authentic character of folk music in choral performances?

- What are the obstacles in transcribing indigenous non-Western folk music and in dealing with the associated copyright issues?

- How can folk music as choral repertoire promote the building of cultural bridges and play a role in the transformation process in South Africa?

2 A children's choir consists of unchanged voices and could be boys only, or girls only, or a combination of boys and girls. In South Africa a distinction can be made between the following types of children's choirs:

- $\quad$ Primary school junior choirs: all choir members attend a specific school, Grades 1 to 3 (7-9 years);

- Primary school senior choirs: all choir members attend the same school, Grades 4 to 7 (10-13 years);

- Regional children's choirs: members come from a wide area and from different schools;

- Girls' choirs: equal-voice choirs comprising girls only (secondary school learners only, or secondary and primary school learners);

- Boys' choirs: choirs consisting of boys with unchanged voices (known in German as KnabenchorSSAA). Boys' choirs with changed as well as unchanged voices - for example, secondary school boys' choirs (TTBB) - can be classified with regard to age and sound as 'youth choirs' and not 'children's choirs'.

In this study the term 'children's choir' refers to regional children's choirs as well as primary school senior choirs. A regional children's choir served as research sample.

3 In South Africa English is the language of commerce and science. The 2001 Census shows that $23,8 \%$ of the population speak IsiZulu, 17,6\% IsiXhosa, 13,3\% Afrikaans, 9,4\% Sepedi, 8,2\% English, 8,2\% Setswana, 7,9\% Sesotho, 4,4\% Xitsonga, 2,7\% SiSwati, 2,3\% Tsivenda, 1,6\% IsiNdebele and 0,5\% other (South Africa 2001:Census). 


\section{Research methodology}

Descriptive qualitative research was conducted to find answers to the primary and secondary research questions. The University of Pretoria Jacaranda Children's Choir ${ }^{4}$ served as a sample case study. Fourteen interviews with choral conductors and other role players from different cultures were conducted and questionnaires were completed by 65 national and seven international choral conductors, as well as seven South African composers. Seven participants responded by way of personal communications. Some participants took part in more than one research activity (for example, a questionnaire as well as personal communication, or an interview). In total, 73 research participants (conductors, composers and other role players) from various cultural backgrounds took part in this research.

The content of the semi-structured questionnaires and topics of discussion in personal communications between the researchers and participants focused on the choral repertoire that conductors choose for their concert programmes. Participants were asked to provide their views on the inclusion of folk music from their own as well as other countries, while also identifying benefits and challenges regarding the inclusion of African folk music as part of their choral repertoire. They were also asked to present their views on choral arrangements (as opposed to originally composed choral music). Issues concerning a cappella or instrumental choral music had to be addressed. Finally, participants were asked to provide an overview of the musical styles that they include in their programmes as well as indicate as a percentage the proportion of the specific styles in a programme.

Apart from the questionnaire-based survey conducted in 2004, the content of 198 concert programmes of regional as well as primary school choirs stretching over a period

The University of Pretoria Jacaranda Children's Choir (South Africa) traces its origins back to 1978, when the Pretoria College of Education Girls Choir was established by Margie Spaumer. From this choir the Jacaranda Children's Choir (including girls and boys) was formed with Salóme Hendrikse as conductor. The choir adopted its current name in 1995 and has been performing under the auspices of the University of Pretoria since 2001. This research is partly based on experience, observation and findings built up over a period of twelve years (1993-2003 and 2006-2007) during which Riekie van Aswegen was appointed as conductor. Other conductors of the choir included Dawie Boshoff (2004), Bea van der Sandt (2005) and Michael Barrett (2008-2010). The choir consists of 75 members, between 9 and 16 years, representing the greater Pretoria area. The repertoire of the choir includes various styles. Folk music from South Africa as well as from other countries forms an important component of the repertoire. 
of 37 years (1968-2004) were included in the data analysis. ${ }^{5}$ An analysis of these documents offered an insight into the extent to which folk music has been included in the programmes of South African choirs. The outcome of the data-collection process produced quantitative information, underscoring Dey's notion that, '[r]ather than counterposing qualitative and quantitative data [...], it makes more sense to consider how these can complement each other in social research' (Dey 1993:13-14, 17).

The participants invited to complete questionnaires were selected because they are experienced in this field and have chosen folk music as repertoire for children's choirs. The diversity of South African society was taken into consideration in the selection of research participants, who represented various cultural groups in South Africa. ${ }^{6}$

Although the participating group, the University of Pretoria Jacaranda Children's Choir, is only a sample and therefore not representative of the entire South African children's choir movement, and in particular not of international trends, the data that were obtained and the deductions derived from this information not only provided answers to the research questions, but also touched upon crucial issues that children's choirs face universally. They also represent an invitation to other scholars to join the discourse.

The researchers' own personal background and experience, long-standing participation in choral activities and practical experience as choral conductors played an important motivating role for this research; our observations of choir concerts and choral competitions prior to, and during, this study complement the analysis of the data. This experience has made us acutely conscious of the importance of the choice of repertoire and the challenges arising from selecting folk music as repertoire.

\section{Findings interpreted within the context of the literature}

The literature review revealed many of the challenges and benefits of including folk music in choral repertoire. The data analysis provided an insight into the challenges and benefits for conductors and other role players when they include folk music as repertoire in choir

The analysis consisted of performances of two types of programmes: programmes performed by one single choir, and programmes performed by more than one choir. Firstly, 76 concert programmes (where one choir performed at a concert) of the following regional choirs were analysed: 7 programmes of the Pretoria Children's Choir conducted by Petru Gräbe (1968-1978), 4 programmes of the Pretoria Children's Choir conducted by Tinus Kúhn (1979-1992), 31 programmes of the Tygerberg Children's Choir conducted by Hennie Loock (1974-2004), 4 programmes of the NKP (Teacher Training College of Pretoria) Girls' Choir conducted by Margie Spaumer (1979-1982), 3 programmes of the NKP (Teacher Training College of Pretoria) Children's Choir conducted by Salóme Hendrikse (1984-1992), 17 programmes of the Bloemfontein Children's Choir conducted by Huibrie Verster (1988-2004) and 10 programmes of the UP Jacaranda Children's Choir conducted by Riekie van Aswegen (1994-2002) Secondly, 122 concert programmes in which a variety of choirs performed during one concert (school choirs as well as regional choirs) were also included.

6 Refer to Appendices A-D for more detailed information on the research participants. 
programmes. This section presents an overview related to the sub-research questions posed in the previous section: firstly, addressing the challenges in preserving the authentic character of folk music; secondly looking at the challenges of transcriptions and the availability of transcribed scores of African folk music; and thirdly, exploring the ways in which the use of folk music as choral repertoire in concert programmes can promote the building of cultural bridges and influence perceptions on folk music and choral arrangements.

\section{Challenges in preserving the authentic character of folk music in choral performances}

Conductors and choirs are faced with the challenge of striving to preserve the authentic character of folk music (Tracey 1963:7; Blacking 1967:5-6). ${ }^{7}$ Factors such as the correct pronunciation and knowledge of the textual meaning, suitable movements and accompanying instruments should be taken into account. This is confirmed by Lundquist and Szego, who underline the importance of an understanding and appreciation of the social and cultural context of a folk song, before an 'outsider' attempts to perform these songs. They maintain that 'outsider' performers will even then gain only a limited understanding of the context (Lundquist \& Szego 1998:17).

Understanding the text and context of a folk song offers the possibility of interpreting the song as honestly and authentically as possible. The text of a folk song is a valuable source of information on the context of the song. It is therefore important that the conductor and choir members understand the meaning of the text and share the content and some context verbally or as part of concert programme notes with the audience (Gräbe 1991:87). As Blacking states: 'In almost every song, there is some phrase or expression which refers to a custom or belief, so that the text may give us a deeper insight into the patterns of the Venda culture' (1967:33). Although Blacking refers to Venda culture in particular, we believe that this principle is valid with regard to the folk music of any other cultures. Aspects of authenticity that are discussed below include performing folk songs in their original language, movement as integral part of singing African folk songs, variations in folk songs, and dances and instrumental accompaniment as part of African folk songs.

\section{Performing folk songs in the original language}

This article deliberately steers away from the discourse on historically informed performance practice (HIPP) (see for example Butt 2002; Viljoen 2008) and concentrate on the research respondents' views on authenticity. 
An important aspect of an authentic performance lies in the correct pronunciation of the language of origin. A translation of a text rarely has the same impact as the original and thus complements the music less than the original text does (Pohjola 1993:112, 113). Therefore the ideal is to perform folk music in the original language and to ensure correct pronunciation. This is a valid condition for original compositions as well as folk music. It is helpful to have a mother-tongue speaker to assist the choir with the pronunciation in performance, or in making a recording. Pohjola maintains that just because children are choir members is no excuse for careless pronunciation. 'Audiences experience songs delivered in their own language as a mark of esteem and respect. The degree of respect is naturally dependent on just how well the song has been rehearsed' (Pohjola 1993:113). Pohjola points out that little language flaws that at times creep into a performance may elicit good-natured smiles, but they should nevertheless be avoided (Pohjola 1993:113). Feedback in the questionnaires indicated that participants agree that the correct pronunciation plays a vital role when performing folk music in the original language and that it reflects the choir's respect for the specific cultural group (Meerholz 2004; Spaumer 2004). Verster (2004) concurs that folk music that is not performed in the original language does not have the same appeal and that the correct pronunciation of the folk song in its original language is vital. Performances of folk songs in the original language must thus be well prepared and attention to pronunciation is thus a prerequisite for authentic choral performances.

\section{Movement as integral part of African folk songs}

Movement and dancing form an integral part of indigenous sub-Saharan African music (Carrol 1956:45; Tracey 1962:29) and performance should present the intertwined nature of the musical arts in the striving for authenticity. Ghebo describes dances as 'the most serious aspect of our [African folk] music. It is through them that we express our deepest emotions' (1954:63). The combination of singing and dancing is typical of the performance of most African folk songs and contributes vitality, energy and visual impact to their execution. Surprisingly, many of the transcribed African songs for children's choirs available in the industry do not make any reference to movement or to supporting audiovisual media. As already recommended for pronunciation, it is equally important to rely on cultural insiders, or on visual recordings of authentic performances, to assist the choir with authentic dances or movements to accompany the song. However, we have observed that some secular and sacred African songs are traditionally performed without 
movements. Gräbe (2004) has pointed out that it is consequently important to note that not all African folk songs are performed with choreography.

\section{Variations in folk songs and dances}

Another challenge that conductors face in their quest to perform folk music as authentically as possible is the fact that there are many variations of particular folk songs and dances performed by different groups in different areas. During concerts, choir competitions and at choir rehearsals we have encountered variations in the melodies and rhythms of songs, specific combinations of songs, as well as variations in the choreography. This observation is confirmed by Blacking: 'There will always be variations that depend on the circumstances of the performance and the personality of the performers' (1967:29). While one should strive towards authenticity, it is also necessary to keep in mind that the performances of folk songs may vary in different regions and as performed by different choirs (Mminele 2004). ${ }^{8}$

\section{Instrumental accompaniment as part of African folk songs}

Some interviewees raised the question of whether instruments such as drums should form part of the accompaniment of African folk songs in South Africa. There is also evidence that indigenous vocal performances included the use of musical instruments such as musical bows (Dargie 1988). According to Gräbe (2004), African folk music in South Africa is mainly performed vocally. According to Rycroft, 'there is in fact a strong indigenous precedent for choral singing. Traditional music in South Africa, unlike the instrumental and percussion-based music of more northerly Africa, has always been predominantly vocal' (1991:9).

In an interview Mminele (2004) supports the view that the inclusion of instruments for example, drums - to accompany these songs is not a given in African folk music performed in South Africa. His personal view is nevertheless that South African choirs do not utilise African instruments enough. He remarked in this interview:

It is true that traditional African music in South Africa is mostly performed only vocally and without the accompaniment of African instruments - I think that should change: South African choirs should include more instruments with their choral performances. South African choirs should experiment more with African instruments. (Mminele in Van Aswegen 2005:322)

Mminele has conducted the Rimonare Primary School Choir [1976-1980], as well as several mixed choirs in Mamelodi and is an adjudicator of choir competitions nationally. 
Mminele attributes the lack of inclusion of instruments as accompaniment to the fact that some African conductors do not make an effort to learn how to play the various African instruments. As adjudicator during choir competitions, he has observed that choirs with Western singers generally tend to put effort into doing research and involve specialists to assist them to achieve authenticity.

\section{Challenges of transcribing and arranging African folk music}

Challenges with regard to transcribing folk music and respecting copyright are closely linked to the availability of scores for African folk songs for choirs. A basic problem experienced by conductors with the inclusion of African folk music is the lack of printed music for equal-voice choirs (Van der Walt 2004:9; Van Aswegen 2005:3-18).

\section{Availability of scores of African folk music}

According to Mminele (2004), there are not many equal voice choirs, especially among regional choirs, in African communities. Consequently little material is transcribed or arranged for children's choirs. Mminele stresses the fact that more should be done to promote folk music, since children reveal a lack of appreciation of their own folk music. Another aspect that he addresses is the use of mixed choral music (choral works composed for a combination of sopranos, altos, tenors and basses) as prescribed material for primary school children's choir categories in choir competitions. According to him, organisers of choir competitions often prescribe music for mixed choir settings (SATB) for equal-voice children's choirs (SSA), because they might not be aware that tenor and basses can only be found in choirs where boys' voices have biologically changed.

The data analysis from this research indicate that there is a shortage of arrangements of South African folk music for children's choirs, as well as audio media to assist conductors in teaching and performing folk songs as authentically as possible. Conversations and e-mail communication with South African and overseas conductors suggest a universal interest in repertoire of South African folk music. However, some participants pointed out that they experience problems in finding suitable choral arrangements of African folk songs.

In South Africa it would certainly help if you could make a list of all publishers and songs for children's choirs according to the level of difficulty. When I was in Pretoria (ISME Conference, 1998) I tried to look for some African music for my choir. I could hardly find any. (Nikula 2001)

Nikula is the conductor of the Sympaatti Choir, Finland. 
Interviews confirmed that there is a shortage of transcribed equal-voice indigenous African choir music (Diale 2004; $;^{10}$ Mminele 2004; Simelane 2004 ${ }^{11}$ ). These participants attribute the lack of adequate arrangements of African folk songs to the small number of equal-voice regional children's choirs in African communities in South Africa. According to them, there appears to be no regional children's choir movement in black communities, apart from children's singing groups in church context.

Transcription of folk music, generally seen as a very complex task, is an issue that cannot be avoided when dealing with the issue of inclusion of folk music in choral repertoire. The difficulty of transcribing folk music is not unique to Africa, but is a universal problem (Nettl 1998:27). 'Western notation has been a filter that has sorted out so many sides of musical possibilities of expression, and thereby made it poorer [...] Oral music traditions seem to reveal many more aspects' (Solbu 1998:36). Some African scholars are sceptical about the participation of Western musicians in transcribing or performing African folk music. Ndlovu's view reflects this resistance:

I [...] stand in defence of African music against the scorn and assaults it has endured from the West, from time immemorial [...] an alien person would have to conform to local manners, beliefs and behaviour for the mastery of these arts. (Ndlovu 1995:132-133)

However, scholars from African cultures confirm the value of notating African folk music (for example, Nketia 1976:367; Magubane 1998:8; Agawu 2003). Although African folk music is taught by rote in African cultural practices (Smith 1962:9), both transcriptions and the oral performance folk music play an important role. Tracey underlines the importance of preserving African folk music art, since 'forms simply disappear over time' (Tracey 1991:3).

Transcriptions could also be seen as a form of re-conceptualising the music, an act that enables researchers to document folk music performed by a certain cultural group in a specific time and space. However, when choosing repertoire for choral performances, it is very important to gain knowledge of the cultural context of a particular song (Lundquist \& Szego 1998:17; Nettl 1998:27). Some folk songs in African cultures, for example, form part of initiation processes and may only be performed by the boys or girls participating in these rituals. These songs are considered as inappropriate material for public performances.

10 Diale was the conductor of the Madidi Primary School Choir [1992-1999] and the Boitemogelo Primary School Choir [2000-2004].

11 Simelane is the conductor of the Spoornet-Johannesburg choir and the Thokoza Cantare Children's Choir. 


\section{Dealing with issues of copyright of African folk music}

Apart from dealing with transcription issues, a much deeper issue deals with the issue of 'permission' to include music from other cultures in a choral programme. Solbu phrases this question as follows:

Can I share borrowed songs with others?' and offers the following answer: I really don't want to misuse what I have borrowed. At the same time, I want others to have pleasure from them. Because every song is, of course, a little treasure. (Solbu 1998:35)

Solbu points out that in contrast to a hundred years ago, today the crossing of international boundaries is commonplace. 'We realize that there is so much more [music] than what is ours, and we dare more and more to approach what belongs to others' (Solbu 1998:29). This trend has implications for the use of folk music in choir work.

Questions arising include: Can a person or a group 'own' a culture and determine who may record or perform folk music? Can a cultural group claim the exclusive right to folk music? Kartomi $(1999: 166,173)$ offers valuable insight into this ethical problem in addressing the issue of transcriptions and performances of indigenous music. She warns against commercial exploitation by ethnomusicologists through sound and video recordings of indigenous music that is then adapted into a popular idiom, or arranged for other performance purposes. This issue of cultural ownership begins to overlap with the questions of copyright of folk music and can become problematic. Kartomi questions the general view that folk music is in the public domain and warns that indigenous music might find itself defenceless where copyright is concerned. Kubik also points out that 'leaders of the famous orchestras [in the Central African Republic during the 1960s] then increasingly borrowed/stole ideas and dance patterns from unknown village singers and instrumentalists' (Kubik 2007:33).

Do we find ourselves at a dead end regarding ethical issues with respect to the copyright of folk music, or is the heritage of folk music part of the global world of the $21^{\text {st }}$ century? The absence of respect for indigenous music might have a negative effect on the growth of folk music: 'The music industry, which is neglecting folk, traditional and nonWestern styles has as a result altered cultural and music behaviour [...] Intelligent value judgements are possible if students have varied and rich musical experiences' (Dzorkpey 2002:108-109). The concern is that not enough is being done to promote folk music to ensure that it receives the status it deserves in the music industry.

Nettl maintains that the outcome of music learned by notation can differ from performances where the music is conveyed orally: 'The normal way for music to be 
transmitted is oral - or aural; one learns music by hearing it [...] Others use notation in manuscript and in print - these two forms may, because of the standardisation available through print, have quite different results' (Nettl 1998:27).

In a lecture during the 2003 Europa Cantat Conference Kari Ala-Pöllänen ${ }^{12}$ used a very apt expression: 'Folk Music is like a butterfly - if you catch it, it dies' (in Van Aswegen 2004b:14). Referring to Finnish folk music, specifically from Sámi or Lappish culture, which is called joiku, he explains that the notation of folk music fails to capture the true indigenous spirit of a song.

Whether folk music should be notated or not thus seems to be a worldwide question. If, however, folk songs were to be accessible only to the original culture group, this would mean that these works would not be available to any other culture group. Although the use of notation of folk music is functional, it remains a challenge to retain the authentic character of the music.

Tracey warns that 'the danger of writing down African music as interpreted by a foreigner in conventional staff notation with plus and minus or other signs to indicate assumed discrepancies from the tempered scale is obvious' (1969:73). Tracey's warning is closely linked with the quest for authentic performances, to which the use of audiovisual material could to some extent provide a solution for ways to deal with the muchneeded cultural context.

Research participants agree that it is challenging to strive towards authentic performances of African folk music. A practical problem identified is that without the assistance of a mother-tongue singer and cultural insider, the effective and authentic performance of African folk music is practically impossible. Since feedback of the research participants reflected the need for assistance in some way to enable them to perform African folk songs as authentically as possible, a combination of notation and supplementary audio-visual material appears to be the solution.

If notation of a choral arrangement of the folk music is available, it is important that the score should be accompanied by other media to assist the choir with the correct pronunciation and movements, and that the choir be supplied with background to the meaning of the song and the context in which it is performed. Audio-visual media such as sound recordings and video material can assist conductors and chorister with correct pronunciation, knowledge of the textual meaning and cultural background of the song, movements and accompaniment. The availability of such media can play a significant role

12 Finnish conductor of the internationally renowned Tapiola Children's Choir (1994-2008). 
to guide choral performers in their attempt to reflect the folk style as authentically as possible.

\section{The role of folk music as choral repertoire in building cultural bridges}

By including folk music as choral repertoire, the singers as well as audiences are enriched not only musically, but also as human beings. In his book Tapiola Sounds Pohjola includes a chapter entitled 'Songs building bridges' in which he states:

Music knows no boundaries. Songs from different countries, sung in their original tongues, have opened gates to the understanding of cultures that differ from our own. It is music that expresses the core of a culture; it evokes images, gives impressions, and touches emotions. These experiences pave the way for an acceptance of diversity and variety in human life. (Pohjola 1993:112)

The policy of the International Society for Music Education (ISME) emphasises the importance of exposing children to music from various cultures: 'We specifically recommend [...] that any musical education [...] take as a point of departure the existence of a world of musics all of which are worthy of understanding and study [...] special attention be paid to the musics of ethnic and social groups comprising the national population' (Lundquist \& Szego 1998:18).

The role of the choir extends beyond choral singing itself: 'A lot of music education is taking place outside the walls of the classroom, which formal education cannot stop' (Dzorkpey 2002:44). Campbell (2002:27) writes on the value of folk music as an essential part of the child's musical education: '[l consider it my] responsibility to expose children to the world of music possibilities. It fits well with their social studies curriculum'. The inclusion of choral activities and specifically folk music as learning material supports the goals and requirements of the National Curriculum for the Arts and Culture learning area. One of the goals of this curriculum is to cultivate an awareness of, and to strengthen, nation building and to nurture a positive attitude towards various South African cultures. 'The developmental outcomes envisage learners who are able to be culturally and aesthetically sensitive across a range of social contexts' (South Africa. Department of Education Curriculum 2002:2).

The importance of including music from various cultures is also emphasised in the curricula of Australia and New Zealand: 'The arts are important for the expression of the life and culture of communities, and contribute to the transmission of values and ideas from generation to generation [...] (and) also communicate cultural contexts' (Government of Western Australia, Department of Culture and the Arts 2004:2). The inclusion of music from children's own cultural heritage, various other cultural heritages from their own 
country and folk music worldwide is thus in line not only with guidelines from the South African curriculum, but also with trends in outcomes-based curricula in countries such as Australia and New Zealand.

Solbu argues that it is just as important to include folk music from a group's own culture as folk music from other cultures:

To explore other cultures can be a way of fleeing from one's own culture. But it can also be a means of searching for a supplement to one's own culture, something which expands, makes whole or creates perspectives about one's own culture, and which places that with which we are familiar into a larger framework, thus revealing new aspects of it [...] I cannot escape from my own identity, but I can enrich it. The deeper a tree's roots, the further its branches can extend without toppling it. (Solbu 1998:31)

Choral singing and the choice of repertoire can play a role in the process of integrating cultures. Lundquist and Szego refer to the 'major role' of music in the 'integration of culture, the maintenance of ethnic identity' and furthermore note its 'usefulness in the solution of social and political problems in inter-ethnic and multi-ethnic societies' (Lundquist \& Szego 1998:18).

In the process of developing a spirit of respect and understanding between various cultures, cross-influences between cultural groups often occur. Blacking believes that 'cultural analysis of musical sound may help us towards an explanation of this relationship between life and music' (Blacking 1967:198). Kruger supports this view, stating that 'the study of musical thought can make a contribution to social analysis, thus paving the way for cultural policy in education and other areas' (Kruger 2007:55).

Choir members of the University of Pretoria Jacaranda Children's choir were asked how they experience the inclusion of folk music in the choir's repertoire and selected responses are provided below to illustrate their views:

We are a choir from Southern Africa - that makes us Africans; therefore I find it essential to include African songs as well as traditional African 'tin can' and 'gumboot dances' in our repertoire. These songs highlight our rich, cultural and colourful heritage. We are a rainbow nation and these songs are uniquely special and symbolic of our multi-racial community. They are bold, yet humble at the same time and provide entertainment to many foreigners and South Africans alike! These songs and dances are just some of the many fascinating beauties that Africans have to offer the wide world. (Choir member - 16 years)

I am inspired about learning music which I as a partly Xhosa child can understand. I think singing African music is wonderful and we should keep going it strong. (Choir member - 12 years)

African music is an expression of love, wisdom and courage. To me, it is a unique form of music - a work of heart. When listening to African music, be it worship, songs of love or 
wisdom, you can't help but feel inspired by its strong pulsating beat. What would South Africa be without the rhythm that African music brings? (Choir member- 14 years)

I think these songs bring our country together. Last year when we had a concert it proved its point when we sang African songs with black people. All racism was 'erased'. It had a wonderful rhythm and beat. Doing the movements is a lot of fun. These songs show a lot of love and unity. (Choir member -14 years)

\section{The role of folk music as choral repertoire promoting social transformation in South}

\section{Africa}

Now that the role of folk music in building cultural bridges has been discussed, the issue of the role of folk music in promoting social integration in South Africa can be addressed. Examples of mutual influences between the music of indigenous groups are often found in South African folk music and can be seen as a commemoration of diversity in South African folk music. But celebrating the diverse nature of South African culture is not always experienced as a positive step by all scholars: 'Many intellectuals have been highly critical of the rainbow nation project or the celebration of many cultures, arguing that it emphasises differences, celebrate[s] what we don't have in common, does not challenge us to change our prejudices, but makes us feel comfortable with them [...] and promotes ethnic chauvinism' (Duphelia-Mesthrie 2000:27). It is clear that some scholars are sceptical about the celebration of cultural diversity in South Africa.

However, in feedback received in questionnaires some participants point out that folk music as repertoire has unique social implications in a South African context: 'This [South African folk songs] is most valuable for the choristers. It opens their minds and hearts to other cultures' (Ashleigh-Botha 2004) The question to be asked is whether folk music as choral repertoire can play a role in the transformation process in South Africa. Kruger argues that the role of music in South African society is underestimated and can play a more significant role in cultural and social transformation:

Musical thought in South Africa often is neglected to the point where it is under-utilised and even unrecognised as a cultural resource [...] musical thought is effective as a cultural resource in societies in which musical performance is an integral aspect of everyday life, it has a critical social function, and education through music is a social objective. (Kruger 2007:55)

The argument that music, and what choirs choose to sing, could serve as a vehicle for social and cultural transformation in South Africa, has received some attention in the South African media. Jonathan Jansen ${ }^{13}$ has doubts about the degree of success of

13 Prof. Jonathan Jansen was the former Dean of the Faculty of Education at the University of Pretoria, South Africa and since 1 July 2009 has been the Vice-Chancellor and Principal of Free State University, South Africa. 
integration and the achievement of racial diversity in schools and universities after ten years of democracy in South Africa (Jansen 2004:21). He asks: 'What can schools and universities do to promote the kind of interaction that will develop a wider sense of citizenship, compassion and community, so that children and students can learn to live together?' One of the factors discussed by Jansen is the choice of repertoire for choir programmes. He investigates the following question: 'What do school and university choirs sing?' In this article Jansen discusses the possibility that the personal convictions of a conductor and/or external pressures around social and cultural integration might play a role in the choice of repertoire.

It is common practice for children's choirs from all over the world to include folk music from their own culture on international concert tours. Although African music deserves a place in any choral repertoire from South African choirs, questions arise about the low frequency of indigenous Afrikaans music ${ }^{14}$ in the repertoire of concert programmes, especially those presented abroad. Why do folk songs from other cultures often seem more alluring, while a group's own culture is neglected? Solbu suggests (1998:31) an answer:

Could it be that we borrow songs from others because the grass seems greener on the other side of the fence, or is it perhaps true that music, which others perform well, is more appealing to us than our own, which we may not yet have mastered? Could the constant exploration of other musical cultures be the result of the fact that I no longer recognize myself in my own? (Solbu 1998:31)

Including folk music from a group's own culture as well as embracing other cultures can be regarded as equally important in choir concert repertoire.

A further debate in the media deals with the balance between African and Afrikaans folk music in repertoire chosen for choir competitions. The focus is placed on choirs that give preference to African folk music as repertoire for competition purposes abroad, even though the majority of choir members of a specific choir could be Afrikaans speaking. Issues related to the inclusion of African and Afrikaans music are raised in a South African newspaper, Rapport (18 July 2004), which asked: Is it important for Afrikaans-speaking choirs to include Afrikaans repertoire? In this debate the Stellenbosch University Choir and its conductor, André van der Merwe, were criticised for their choice of repertoire. This choir had received exceptional accolades during their participation in the 2004 Musica

14 The term 'Afrikaner' is derived from the Dutch word Afrikaander, which referred to the original colonists. Dr J A Heese notes in his book, Die herkoms van die Afrikaner 1657-1867, that the Afrikaner is constituted of $34,8 \%$ Dutch, 33,7\% German, 13,2\% French, 6,9\% non-whites, 5,2\% English, 2,7\% other nationalities and 3,5\% unknown (cited in Albertyn 1971:Part 1, 203). Afrikaans is the language that this cultural group speaks. Afrikaans developed from Dutch and is spoken by some white and coloured people in South Africa and Namibia (see Ponelis 1993). 
Mundi. ${ }^{15}$ Though the choir members are predominantly Afrikaans speaking, the choir did not include Afrikaans repertoire. According to the report, several letters criticised the conspicuous absence of Afrikaans folk songs or compositions with an Afrikaans text. One of the comments on the choir's repertoire claimed: 'It is a masquerade and a poor attempt at political correctness' (Botes \& Schoeman in Malan 2004:6). ${ }^{16}$

The reaction of the conductor to this criticism gives an insight into how a conductor makes decisions on the choice of repertoire. According to André van der Merwe (in Malan 2004:6), the South African composer Roelof Temmingh was commissioned to compose a work specially to be performed by the Stellenbosch University Choir during the competition. In this work Temmingh uses the German text of Psalm 8. Van der Merwe states that this composition 'displays the choir's ability to perform contemporary techniques and vocal tendencies' as well as the skills and high standard of South African composers. Van der Merwe's further explanation of why African folk songs and not indigenous Afrikaans folk music were included in the folklore category indicates how participation in competitions influences the conductor's choice of repertoire; he mentioned that African folksongs were chosen above Afrikaans folk songs

... since indigenous African choral music is dramatic, dynamic and spectacular [...] We decided on an African theme since we felt that African folk songs are more expressive and theatrical and would receive more acclaim from the adjudicators. (Van der Merwe in Malan 2004:6)

Although this debate presents the argument that Afrikaans choirs should also sing Afrikaans folk songs, it also underlines the idea that performing folk music from other cultures than your own has the ability to build bridges between cultures and cross cultural borders. The reflection of a variety of languages and cultures in the South African choral repertoire could therefore be seen as an important tool in social cultural transformation in post-apartheid South Africa, which now has 11 official languages. Participation in performing the indigenous songs of various cultures can contribute to a lifestyle where intercultural tolerance and respect are the norm.

There is a growing awareness of the value of South African folk music among South African conductors. This is reflected in the prescriptions of various South African

15 Musica Mundi was founded in 1988. It is an international choral organisation that hosts international choral events (including choir competitions and seminars) in various countries throughout the year. Lectures and workshops form part of the activities organised by the Musica Mundi choral academy <http://www.interkultur.com/leftnavi/musica-mundi/>.

16 Because of South Africa's apartheid legacy, Afrikaans was seen as the language of the oppressor. Rassool et al. (2006:538) describe the situation as follows: 'English - the previous colonial language, and Afrikaans - the language of Apartheid neo-colonialism, consolidated a society which was, on the one hand, fractured along the horizontal axis of a racialised ethnicity and, on the other, stratified along the vertical axis of social and economic inequality.' 
choir competitions. The rules of the ATKV Applous Choir Festival, a prestigious national South African choral festival presented annually by the Afrikaans Language and Culture Organisation, for example, require the inclusion of one folk song from a South African culture.

In the foreword to the selection Songs Sung by South African Children the author Brouckaert reflects on how indigenous songs play a positive role in the transformation process in South Africa:

The songs [traditional African songs from South Africa] reflect the rich but harsh reality of social and cultural life in South Africa. As adults we understand how badly we need to change the society we live in, so that our children will have the chance to grow up free from the profound violence of racism and sexism. (Brouckaert 2002:4)

Consequently music, and in this research specifically folk music, could play a positive role in crossing cultural bridges, but it can also be used as a tool in protesting against social prejudice. For decades folk music was also used as a form of political and social resistance as part of the liberation movement in South Africa, and also in the civil rights movement in the USA as part of the formation of an African American identity (Eyerman 2002:446).

We agree with Decker and Kirk (1988:155) that 'a well selected concert - with contrasting moods and with music from various periods and cultures placed in an effective order - provides an audience with imaginative and emotional stimuli'. Performing folk music as part of the concert programme contributes to variety and balance in a choir's repertoire. The inclusion of folk music as choral repertoire builds cultural bridges by cultivating a spirit of respect and co-operation.

\section{Inclusion of folk music in South African choral programmes}

Choral singing forms a vital part of cultural activities in South Africa. 'With the years, choral singing has become the culturally most pursued activity in South Africa. Choral music is one of the dynamic forces in South African music' (Van der Walt 2004:19). A significant driving force is the unique South African milieu, which has an influence on the choice of repertoire, especially folk music (Van Aswegen, 2005:3-6). This research investigated to what extent African folk songs are included as choral repertoire in the programmes of South African children's choirs.

There is a perception among some performers and scholars that folk music is inferior in comparison to the composed repertoire, a view that previously hamstrung the inclusion 
of folk music in choral repertoire. This view of inferiority is reflected in the definition of 'folk music' offered by the second edition of the Harvard Dictionary of Music:

The musical repertory and tradition of communities (particularly rural), as opposed to art music, which is the work of musically trained composers. It generally develops anonymously usually among the uneducated classes [...] Western folksong develops together with artless poems. (Apel 1979:323)

Indigenous music is consequently described as the opposite of Western art music. In the New Harvard Dictionary of Music folk music is described as part of an oral tradition, often performed in a relatively simple way. It is 'normally performed [...] used and understood [...] by non-professionals [...] especially by the lower socio-economic classes' (Randel 1986:315). The bias against folk music is clear in the assumption that the folk music is artless and that creators of such music do not have any musical training or expertise and come from a lower socio-economic background.

Kruger (2007:40) maintains that there is a decrease in interest in, and the popularity of, indigenous music among the younger generation in Venda culture. He cites a young Venda saying that 'Tshikona [a traditional Venda bamboo pipe dance] is primitive and for old people'. Kruger emphasises the point that activities within schools can play an important role in the promotion and preservation of folk music. 'Schools also became a useful institution by means of which chiefs would mobilize tshikona teams, and school vacations were often the best times to observe tshikona performances' (Kruger 2007:40). Rycroft (1991:5) points out that 'except among traditionalists in rural areas', African people generally do not value their indigenous folk music.

Music-making has been deeply affected by Westernisation and urbanisation. [...] Generation upon generation of African converts, dressed in Western clothes, were taught to despise and totally reject their own customs and musical traditions, which the missionaries damned as heathen and barbaric. Indigenous music and dancing was replaced by hymns and choir singing, modelled on current European practice and taste, and that form of music making came to be universally adopted and perpetuated as the civilized norm among educated blacks throughout the whole of South Africa. (Rycroft 1991:5)

According to Tracey (1991:4), there is a need for the revival of indigenous folk music. He refers to folk songs as 'irreplaceable' and considers it is a misconception that 'everyone prefers popular music'. Tracey (1991:4) and Avorgbedor (1992:49) underline the importance of support from government bodies to promote folk music. 'A reason for our government's responsibility to support art \& culture is that the traditional arts have an inherent intrinsic value in themselves' (Tracey 1991:3). He further points out that schools and the government can play a much stronger role in strengthening a positive perception of indigenous folk music. 
An African government that has the deepest cultural aspirations of its people at heart should take significant steps towards counterbalancing the overwhelmingly lop-sided arts patronage situation, which has only been exacerbated in recent decades by the growing Western interest in African music and arts. (Tracey 1991:4)

Gbeho had already said in 1954: 'I know that education authorities are beginning to see the great need to preserve this music [...] It must be organized seriously in the schools and then they will grow to appreciate the importance of this aspect of our culture, which is our national heritage' (1954:64).

A contributing factor to the perception among some people of folk music as inferior choral repertoire is the fact that folk music normally has to be arranged for choral purposes. Choral arrangements are often regarded as of a lesser value than original compositions (Van Aswegen 2005:6-11, 6-12). The question that arises is whether choral arrangements of folk music can be compared on equal terms to the standard and quality of original choral compositions? While it is important to include original composed works in the choral repertoire, arrangements of folk music can also play a valuable role in the concert programmes of children's choirs.

The research findings reflect that South African and overseas participants are positive about the use of arrangements of folk music in choir repertoire. With regard to the use of arrangements, participants mentioned certain conditions regarding the use of folk music, indicating that it must be performed as authentically as possible and must be sung in the original language. Research findings underscore the positive value of folk music as choral repertoire. The importance of variety and the inclusion of folk music in a concert programme are underlined by conductors who responded to the questionnaires. Participants were requested to give an indication as a percentage of how their concert programmes were divided into various styles. The data reflected the following percentages with regard to the inclusion of folk music: African folk songs (27.1\%), Afrikaans folk songs (14.7\%), African gospel music (including folk and composed popular music) (29\%) and folk music from other parts of the world (9.7\%).

Feedback from participants indicated that folk music is regarded as an important style to include in concert programmes and that it contributes to variety and balance in a choir's repertoire. The ideal programme does not exclude folk music, but neither should it consist mainly of folk music. The extent to which folk music is included depends on the preferences and vision of the conductor and the type of performance the choir is preparing for. 
An example of South African folk music as well as folk music from other countries as part of the overall repertoire classification in an annual programme is illustrated in Figure 1.

Figure 1: The distribution of music styles presented in the Gala concert programme of the University of Pretoria Jacaranda Children's choir in 2003

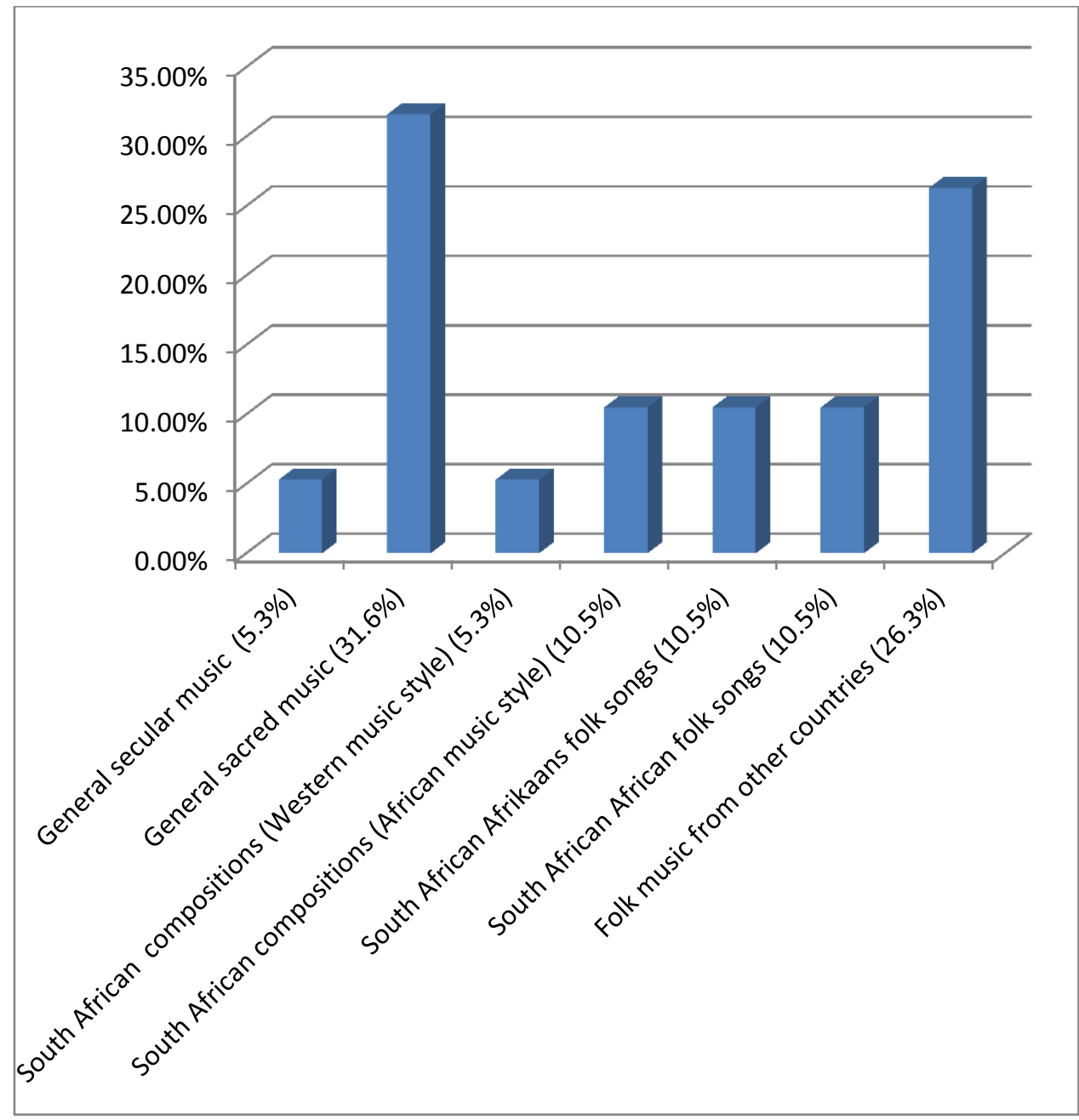

This figure is an illustration of how the programme of the Gala concert of the University of Pretoria Jacaranda Children's choir was compiled in 2003. The diagram shows that the programme was divided into General secular music (5.3\%), General sacred compositions (31.6\%), South African compositions composed in a Western music style (5.3\%), South African compositions composed in an African music style (10.5\%), South African Afrikaans folk music (10.5\%) and Folk music from other parts of the world (26.3\%). A significant percentage of African folk music as well as compositions influenced by African music elements $(21 \%)$ were included. The choir was invited to participate in the international Sympaatti Festival in Finland (2003) and the repertoire was selected with this tour in mind. It is therefore evident that the inclusion of folk music from other countries is determined 
and influenced by international tours as well as by visiting choirs from abroad; through interaction with international choirs, folk music is exchanged and horizons are broadened through exposure to new music from other cultures. This process plays an important role in striving towards creating choral programmes that reflect variety in style.

An analysis of 198 South African concert programmes of regional and school choirs (1968-2004) was conducted. The following graph illustrates the inclusion of African folk songs in these programmes over a period of 37 years.

Figure 2: African folk songs in the repertoire of children's choirs (1968-2004)

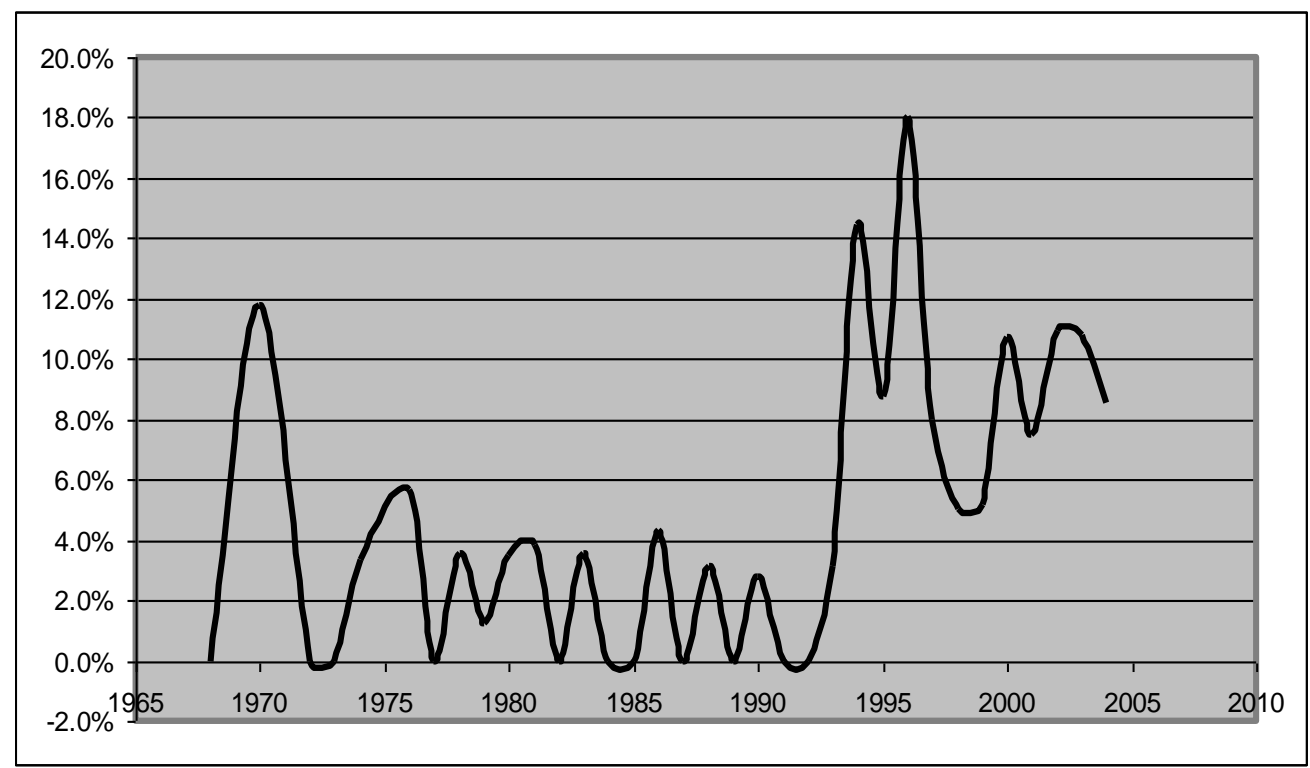

There is a clear increase in the inclusion of African folk music since the 1990s. Though including African folk songs as part of the repertoire was not very common before the 1990s, this figure is influenced by programme data of the Pretoria Children's Choir ${ }^{17}$ in the 1960s and 1970s. An analysis of the programmes of the Pretoria Children's Choir revealed that the conductor of this children's choir, Petru Gräbe,${ }^{18}$ performed pioneering work by including African folk songs in the choir's programmes long before doing so became a trend.

It is significant to note that the data in the above graph indicate the widespread inclusion of folk music in the repertoire of children's choirs regardless of the fact that a number of respondents indicated that they found it difficult to obtain suitable arrangements of African folk music for children's choirs. Some conductors pointed out that once an

\footnotetext{
17 Nowadays called the University of Pretoria Jacaranda Children's Choir.

18 Petru Gräbe was the choir conductor of the Pretoria Children's Choir (1968-1978), the Pretoria University Choir (1978-1998) and the Cantamus Corde Chamber Choir (2001-2007). He also acts as an adjudicator of South African and overseas choir competitions.
} 
arrangement is available, every choir seems to perform it. Consequently it is difficult to continuously find arrangements of African folk songs that audience members would experience as innovative and appealing.

The data show that there is a growing interest in including folk music as choir repertoire. The majority of research participants indicated that folk music from their own country (mother tongue as well as other indigenous cultures) and from other countries is regarded as useful repertoire. Some conductors indicated that they do not feel at home and safe with repertoire in an African style: conductors and choir members find the movements difficult and regard pronunciation and accessing the meaning of the texts as obstacles.

Most participants, however, do make use of African folk music, with the assistance of colleagues from African communities or other sources, such as video recordings. According to this group of respondents, the conductor, the choir members and the audience all have a positive affinity with this folk music.

Several advantages were mentioned with regard to the inclusion of South African folk music: it finds favour with choir members and audiences; there is exposure to different South African cultures; and representative South African folk music is reflected in this way in concert programmes in this country.

Interaction among cultural groups and social integration are topical issues not only in South Africa, but throughout the world. The findings indicate that the participants are mainly positive about the use of arrangements of folk music as choir repertoire and that folk music in South African choir performances plays a positive role in promoting social integration and building cultural bridges. Comments in the questionnaires on the inclusion of African folk music as choral repertoire included the following:

Yes, it can add splendour to a programme. Besides, all those involved learn about different cultures and their musical interpretation and significance. (Hennie Loock)

I'm mad about indigenous music. I believe it speaks to the innermost of all people. (Renette Bouwer)

Almost half of the participants (45.3\%) felt particularly strongly about the inclusion of folk music; $43.8 \%$ indicated that folk music could be used and $10.9 \%$ that it could be used to some extent.

It appears that, generally speaking, the participants from various cultural groups in South Africa are positively disposed towards the inclusion of music from language groups in South Africa other than their own. 
Although I am with an English-medium school, I sing at least one Afrikaans song every year - [I] have a strong Afrikaans tradition. As there are many Xhosa[-speaking members] in my choir, I also include songs in indigenous black languages. (Rina Dippenaar)

Conductors from a Western background are mostly positive about African folk music and conductors, choir members and audiences enjoy choirs sharing folk music from a variety of cultures. Many Afrikaans and English mother-tongue speakers in South Africa have not mastered an African language. Consequently, before an indigenous African song can be learned, conductors need assistance to perform the song authentically with regard to singing, text, movements and accompanying instruments. Respondents maintain that workshops play a useful role in helping conductors to find repertoire of indigenous African songs and to perform the songs correctly. Some participants considered it an obstacle to first do the research, preparation and arrangements required for performing African folk songs.

Some other issues that conductors face when choosing folk music as choral repertoire were not included in the questionnaire survey, but emerged from the data collected from the interviews. One such issue addresses issues of costs and time. To perform African folk music successfully involves additional costs and can be time consuming. Conductors have to rely on specialists to assist the choir with correct pronunciation, choreography, drum accompaniment and general performance style. Some conductors expressed problems in finding competent and available assistants, as well as in making logistical arrangements and providing suitable compensation.

Most respondents who conduct choirs composed mainly of African culture groups feel positive towards songs with an Afrikaans text. They refer in this regard to the 2004 Tirisano competition for which the work 'Loskopvoëltjie' by Salóme Hendrikse was prescribed. A cassette giving the pronunciation of the song was available and helped the choirs in this regard.

If we have enough time, we don't have a problem with singing Afrikaans songs. Loskopvoeltjie is an easy song to learn. We have no problems with the Afrikaans pronunciation. (Dtishego 2004)

Some South African participants from both African and Western backgrounds reported that they do not feel competent in performing folk music foreign to their own culture.

Findings in the interviews, personal correspondence and questionnaires in this research underline the significant role of folk music as choral repertoire. According to respondents, musical enrichment is nurtured and a mutual understanding among various language groups is fostered. One respondent formulated her view in a questionnaire as follows: 
I feel very positive about indigenous African songs. Folk music / indigenous songs, because of their oral transfer, are always guaranteed to be highly singable and to be 'hits' (democratically preferred by ordinary people), thus a 'nice' song which sings well. Secondly, because our indigenous music has a strong musical and emotional influence on the development of an ego-identity. Furthermore, it is beautifully sparkling and enjoyable! [It is] extremely singable as it is composed from and by the voice. (Stefnè van Dyk)

It therefore seems that the inclusion of folk music in choral repertoire can contribute positively towards building cultural bridges.

\section{The influence of African folk music on South African choral compositions}

The value of folk music in the choral repertoire, as a way to build bridges between diverse cultures, is further emphasised by the influence of folk music on composed choral works. Many Western musicians are attuned to, and influenced by, African folk music. Western compositions reveal an increasing number of African-inspired elements. The trend for folk music, specifically African folk music, to become popular in the choral repertoire is also noticeable in South African compositions. Elements of African folk music play a significant role in South African choral compositions. This cross-influencing of music of the various culture groups in South Africa, as well as of new and old music, is aptly described in the preface written by Nelson Mandela to Magubane's Vanishing cultures of South Africa:

South Africa is proud of its diverse cultural wealth and traditions. Although some cultural traditions have been forsaken, others still form an integral part of our daily life, often blending with each other and with modern elements to present a fascinating juxtaposition of old and new. (Magubane 1998)

Examples of this are children's choir works by contemporary South African composers, such as Jelelele and African Dawn by Niel van der Watt and Tu Pauperum Refugium composed by Hendrik Hofmeyr. Other examples of choral compositions reflecting elements of African folk music (for example, call and response) for mixed choirs composed by African composers include Vuka, Vuka, Debora! by John Knox Bokwe and Mintirho Ya Vulavula by SJ Khosa. Several compositions by Michael Mosoeu, for example, Ruri and Liphala, have been used as prescribed choral works by provincial and national school authorities in South Africa (Khumalo 1988:14). An example of combinations of music in an African and Western style can be seen in the Xhosa hymn 'Nkosi Sikelel' iAfrika' (God bless Africa), composed in Western choral style in 1897 by the Reverend Enoch Sontonga. This African composition has been combined with a part of the old Western South African national anthem has been the official anthem of South Africa since 1994. This combination of two cultural musical approaches in the South 
African national anthem is a clear example of the way in which cultural barriers can be breached through music. According to Tracey,

[it] is to the traditional arts that creative artists, whatever cultural world they live in, are continually looking for the deepest kind of cultural inspiration. [...] because these arts represent the refinement of centuries of artistic growth, inspiration and development. (Tracey 1991:4).

Newly composed choral works inspired by African music, or arrangements of folk music for choirs, contribute to the repertoire for choirs worldwide.

\section{Conclusion}

In this article we have shared our views on the inclusion of folk music in the concert programmes of children's choirs and the challenges and benefits of cultural diversity. Various issues have been addressed.

The research indicated the absence of a wide enough variety of choral arrangements of folk music for equal-voice choirs. There is also a shortage of audiovisual material to guide conductors and choir members in the correct pronunciation of the text, or to assist them in understanding the cultural background to the music, or to practise the authentic movements that form an important aspect of the music. Transcriptions (re-conceptualisations) enable researchers to document folk music performed by a certain cultural group in a specific time and area. However, it is equally important to gain knowledge of the cultural context of a particular song (contextualisation).

A combination of notation and additional audio-visual material seems to be the solution to addressing these challenges concerning the preservation of the authentic character of folk music.

We conclude that it is possible to aspire to represent a folk song from a culture different from one's own as authentically as possible, but not to claim that it is a truly authentic performance. A secondary performance can never equal an original one, or be seen as equivalent to primary performances. Neither is this the aim of a secondary performance. However, a conductor and choir can endeavour to reflect folk music as honestly as possible by performing folk songs in the original language, using authentic movements, if this is required by a specific cultural group's folk songs, and including appropriate instruments as accompaniment of folk songs.

The ethical problem of copyright arises when folk music is transcribed, arranged, performed and used for commercial purposes. It seems that it is in the interests of the global community that musicians have access to the indigenous music of the world and enjoy the freedom to transcribe, arrange and perform folk music. The claim that Western 
scholars or musicians do not have the right to transcribe or perform African music can only be consistent and valid if it is accepted that all cultural groups have a monopoly on their own music. Such a view would have left humankind without the possibility, for example, of singing 'Brother Jacob' in a vast number of languages! Nevertheless, a consciousness of the value of folk music and an awareness of issues on copyright should be cultivated.

A driving force that influences choral repertoire in South Africa is the unique and dynamic South African cultural environment. Elements of African folk music play a role as elements in newly composed South African choral works. South Africa has a valuable treasure of both folk music and composed works in both the Western and African idiom.

It is generally accepted that a choir programme should reflect variety of forms, that it should include original compositions, and that there should be a balance between $a$ cappella and accompanied works. It is equally important that children should enjoy exposure to folk music from their own heritage as well as various other kinds of music of their own country and indigenous music from other parts of the world. The inclusion of indigenous Afrikaans and African music in South African concert programmes provides balance and variety, reflects the cultural diversity of South Africa and can play a positive role in promoting the transformation process in South Africa.

A general acceptance of, and respect for, other cultures regardless of racial and other differences are strengthened in this way. Choirs and audiences are exposed to a wider variety of music styles and musical horizons, while their general vision of life may be broadened. An opportunity is created for new musical experiences and modes of expression through sound, while the repertoire is enriched by becoming more varied as well as balanced. By performing folk songs, children are encouraged to take pride in singing songs in their own mother tongue as well as in other languages in South Africa.

Despite the various challenges or 'juggling acts' required to develop the repertoire, folk music in the choral repertoire has important benefits to offer, especially in bridging cultural differences. Children in choirs, the conductors and composes involved, and the audiences enjoying the performance can be influenced in a positive way by being exposed to folk music from various cultural groups in South Africa.

As we experience the journey of folk music as choral repertoire we encounter pitfalls (challenges), but also bridges (benefits). The value of building cultural bridges through folk music overshadows the challenges.

\section{References}


Agawu, Kofi (2003). Representing African Music: Postcolonial Notes, Queries, Positions. New York and London: Routledge.

Albertyn, C F (1971). Ensiklopedie van die wêreld: Deel 1. Stellenbosch: Gothic.

Apel, W (1979). Harvard Dictionary of Music, second edition. London: Heinemann.

Apfelstadt, H (2000). 'First things first: selecting repertoire.' Music Educator's Journal,

87(1):19-22, 46

Ala-Pöllänen, K (2004). Comment in questionnaire.

Ashleigh-Botha, C (2004). Comment in questionnaire.

Ashworth-Bartle, J (2003). Sound Advice - Becoming a Better Children's Choir

Conductor. New York: Oxford University Press.

Avorgbedor, D (1992). 'The impact of rural-urban migration on a village music culture:

some implications for applied ethnomusicology.' African Music, 7(2):45-57.

Blacking, J (1967). Venda Children's Songs. A Study in Ethnomusicological Analysis.

Johannesburg: Witwatersrand University Press.

Bouwer, R (2004). Comment in questionnaire.

Brouckaert, L (2002). Songs Sung by South African Children. Cape Town: Gatesville

Grassroots EducareTrust.

Butt, J (2002). Playing with History: the Historical Approach to Musical Performance.

Cambridge: Cambridge University Press.

Campbell, P S (2002). 'Music education in a time of cultural transformation.' Music

Educator's Journal, 89(1):27-32.

Carrol, K (1956). 'Yoruba Religious music.' African Music, 1(3):45-47.

Carter, D (2010). 'A bridge too far? Cosmopolitism and the Anglo-American folk music

revival, 1945-65.' European Journal of American Culture, 29(1):35-51.

Dargie, D (2004). Xhosa music: Its techniques and instruments, with a collection of songs.

Cape Town: David Phillip.

De Beer

, S (2004). 'Prof Jansen se siening só nie aanvaarbaar.' Rapport, 22 August, 2.

Decker, H A \& Kirk, CJ (1988). Choral Conducting - Focus on Communication.

Englewood Cliffs, New Jersey: Prentice Hall.

Dey, I (1993). Qualitative Data Analysis: A User-friendly Guide for Social Scientists.

London: Routledge.

Dhupelia-Mesthrie, U (2000). From Cane Fields to Freedom: A Chronicle of Indian South

African life. Cape Town: Kwela Books.

Diale, D (2004) Personal communication, Pretoria, 7 August.

Dippenaar, R (2004). Comment in questionnaire. 
Dtishego, E (2004). Personal communication with a teacher assisting choirs in Mamelodi. Pretoria, 10 September.

Dzorkpey, T K (2002). Training music teachers for multicultural education in South Africa.

Bloemfontein: University of the Orange Free State, unpublished Master's dissertation.

Education Review Office. (1995). 'Arts in the New Zealand curriculum, No. 2, Autumn.' $<$ http://www.ero.govt.nz/Publications/eers1995/95no2hl.html> accessed 25 August 2004.

Eyerman, R (2002). Music in Movement: Cultural Politics and Old and New Social Movements. Qualitative Sociology, 25(3):443-458.

Gbeho, P (1954). 'Music of the Gold Coast.' African Music, 1(1):62-64.

Gordon, L (1989). Choral Director's Rehearsal and Performance Guide. New York: Parker.

Government of Western Australia, Department of Culture and the Arts (2004). Curriculum framework, p. 2. <http://www.cultureandarts.Wa.gov.au/DepartmentofCultureand the Arts/Initiativesproject.html> accessed 25 August 2004.

Gräbe, P (1991). 'Die opstel van 'n konsertprogram en enkele aspekte van vertolking.' In S H Hendrikse (ed.), Die Groot Afrikaanse Koorleiersgids. Pretoria: Van Schaik, 84-93.

Gräbe, P (2004). Personal communication. Pretoria, 7 September and comments in questionnaire.

Jansen, J (2004). 'Ras spook nog in die onderwys.' Rapport, 15 August, 21.

Kartomi, M J (1999). 'Ethno-musicological education for a humane society: ethical issues in the post-colonial, post-apartheid era.' Journal of International Library of African Music, 7(4):166-174.

Kruger, J (2007). 'Singing psalms with owls: a Venda $20^{\text {th }}$ century musical history, part two: Tshikona, beer songs and personal songs.' African Music, 8(1):36-59.

Kubik, G (2007). Pierre Gwa - Mpyemõ guitarist: his songs and their sources - Central African Republic, 1966. African Music, 8(1):21-35.

Khumalo, J S (ed.) (1998). South Africa Sings Volume 1. Johannesburg: SAMRO.

Lamb, D (2006). Singing diverse repertoire in the Elementary School Choir. Choral Journal, 46(10): 8-16.

Loock, $\mathrm{H}$ (2004). Comment in questionnaire. 
Lundquist, B \& Szego, C K (1998). Musics of the World's Cultures: A Source Book for

Music Educators. Reading: Callaway International Resource Centre for Music

Education (CIRCME) for the International Society for Music Education (ISME). Magubane, P (1998). Vanishing Cultures of South Africa. Cape Town: Struik Publishers. Malan, M (2004). 'Wenkoor kry die wind van voor oor Afrikaans.' Rapport, 18 July, 6. Massed Choir Festival $10^{\text {th }}$ Anniversary Music Book (1998). Johannesburg: Sowetan / Caltex / SABC 1.

Meerholz, K (2004). Comment in questionnaire.

Miller, K E (1979). Handbook of choral music selection, score preparation and writing.

New York: Parker Publishing.

Mminele, B (2004). Personal communication. Pretoria, 16 August.

Ndlovu, C (1995). 'Should African music be notated?' Conference Proceeding at the

Tenth Symposium on Ethnomusicology at Rhodes University, 30 September - 2

October 1991 In C. Muller (ed.), African Music, September 1995, 132-136).

Nettl, B (1998). 'An ethnomusiciological perspective.' In B Lundquist \& C K Szego (eds),

Music of the World's Cultures: A Source Book for Music Educators. Reading:

Callaway International Resource Centre for Music Education (CIRCME) for the International Society for Music Education (ISME), 23-28.

Nikula, P (2001). E-mail correspondence, 30 October.

Nketia, J H K (1976). 'Understanding African music.' In F Callaway (ed.), Challenges in Music Education, Proceedings of the $11^{\text {th }}$ World Conference of the International Society for Music Education, 5 - 12 August 1974. Perth: University of Western Australia \& Music Board of the Australian Council, 362-367.

Pohjola, E (1993). The Tapiola Sound. Fort Lauderdale: Walton.

Ponelis, F (1993). Afrikaans Language; History; Social Aspects. Frankfurt am Main and New York: P Lang.

Randel, D M (ed.) (1986). New Harvard Dictionary of Music. Cambridge, Mass.: Harvard University, 315.

Rassool, N, Edwards \& V Bloch C (2006). 'Language and development in multilingual settings: a case study of knowledge exchange and teacher education in South Africa.' International Review of Education, 52(6):533-552.

Rycroft, D (1991). 'Black South African urban music since the 1890s; Some reminiscences of Alfred Assegai Kumalo (1879-1966).' African Music, 7(1):5-31.

Simelane, $T$ (2004). Personal communication, Johannesburg, 18 September.

Smith, E M (1962). 'Musical training in tribal West Africa.' African Music, 3(1):6-10. 
Solbu, E (1998). 'A performance perspective.' In B Lundquist \& C K Szego (eds), Music of the World's Cultures: A Source Book for Music Educators. Reading: Callaway International Resource Centre for Music Education (CIRCME) for the International Society for Music Education (ISME), 29-37.

South Africa. 2001. Census. Pretoria: Statistics South Africa.

South Africa. Department of Education Curriculum (2002). Revised National Curriculum

Statement. Grades R - 9 Policy. Pretoria: Arts and Culture Gazette No: 23406,

Vol. 443, May 2002.

Spaumer, M (2004). Comment in questionnaire.

Tracey, A (ed.). (1991). 'A word from the editor.' African Music, 7(1):3-4.

Tracey, $H$ (1962). 'The arts in Africa, the visual and the aural.' African Music, 3(1):20-32.

Tracey, H (1966/1967). 'Musical appreciation in Central and Southern Africa.' African

Music: 4(1):47-55.

Tracey, H (1969). 'Measuring African scales.' African Music, 4(3):73-77.

Van Aswegen, H J (2004a). Cantando Gaudeamus. Europa Cantat Junior Conference (13-21 July 2002) - Report, (53):8-10.

Van Aswegen, H J (2004b). Cantando Gaudeamus Europa Cantat Junior Conference (13-21 July 2002) - Report, (54):14.

Van Aswegen, H J (2005). Repertorium vir kinderkore 'n Suid-Afrikaanse perspektief.

Pretoria: University of Pretoria, unpublished doctoral thesis.

Van Dyk, S (2004). Comment in questionnaire.

Van der Walt, A (2004). 'Choral singing in South Africa.' International Choral Bulletin, 23(3):19.

Van Pletzen, C C (1995). Die aktiwiteite van geselekteerde skoolkore en hul invloed op

die musiekopvoeding in die Oranje-Vrystaat. Bloemfontein: University of the

Orange Free State, unpublished master's dissertation.

Verster, $\mathrm{H}$ (2004). Comment in questionnaire.

Viljoen, M (2008). 'African and European voices: speaking 'in harmony' as contemporary authenticity.' Journal of the Musical Arts in Africa, 5:19-36.

\section{Appendices}

\section{Appendix A}

Table 1: Distribution of questionnaire

\section{Participants}




\begin{tabular}{|l|c|}
\hline South African conductors of regional children's choirs & 13 \\
\hline South African conductors of school choirs & 44 \\
\hline Overseas conductors of regional children's choirs & 7 \\
\hline Composers of children's choir repertoire & 7 \\
\hline Officials involved in choral organisations & 2 \\
\hline Distributor of printed music & 1 \\
\hline $\begin{array}{l}\text { Persons interviewed and communicated with by mail } \\
\text { or e-mail (This group did not return questionnaires) }\end{array}$ & 10 \\
\hline Total & 84 \\
\hline
\end{tabular}

\section{Appendix B}

Table 2: Geographic location of participants, who completed questionnaires

\begin{tabular}{|l|c|}
\hline \multicolumn{1}{|c|}{ Location } & Number \\
\hline Participants from South Africa & 29 \\
\hline Gauteng & 1 \\
\hline Kwazulu-Natal & 2 \\
\hline Mpumalanga & 3 \\
\hline North-West Province & 1 \\
\hline Northern province & 7 \\
\hline Eastern Cape & 1 \\
\hline Southern Cape & 3 \\
\hline Northern Cape & 1 \\
\hline Free State & 8 \\
\hline Western Cape & 56 \\
\hline Total & \\
\hline \multicolumn{2}{|c|}{} \\
\hline Participants from other \\
countries & 1 \\
\hline Belarus & 3 \\
\hline Finland & 1 \\
\hline Greece & 1 \\
\hline Norway & 1 \\
\hline Canada & $\mathbf{7}$ \\
\hline Total & $\mathbf{6 3}$ \\
\hline \multicolumn{2}{|l|}{} \\
\hline Grand total & \\
\hline
\end{tabular}




\section{Appendix C}

Table 3: Geographic location of all participants

\begin{tabular}{|l|l|c|}
\hline \multicolumn{1}{|c|}{ Data collection } & \multicolumn{1}{|c|}{ Places } & $\begin{array}{c}\text { Number of } \\
\text { participants }\end{array}$ \\
\hline Interviews & $\begin{array}{l}\text { South Africa, Gauteng: Pretoria (3) } \\
\text { South Africa, Gauteng: Boksburg (1) } \\
\text { South Africa, Gauteng: Mamelodi (4) } \\
\text { South Africa, Gauteng: Johannesburg (2) } \\
\text { South Africa, Gauteng: Garankua (1) } \\
\text { South Africa, Northwest Province: } \\
\text { Potchefstroom (1) } \\
\text { South Africa, Orange Free State, } \\
\text { Bloemfontein (2) }\end{array}$ & 14 \\
\hline $\begin{array}{l}\text { Personal } \\
\text { Communication }\end{array}$ & $\begin{array}{l}\text { South Africa, North-West Province, } \\
\text { Potchefstoom (1) } \\
\text { South Africa, Gauteng, Petoria (1) } \\
\text { South Africa, Kwazulu-Natal, Drakensburg } \\
\text { (1) }\end{array}$ & \\
\hline $\begin{array}{l}\text { Finland (2) } \\
\text { Germany (1) } \\
\text { Canada (1) }\end{array}$ & 7 \\
\hline $\begin{array}{l}\text { Questionnaires: choir } \\
\text { conductors }\end{array}$ & South Africa & 7 \\
\hline $\begin{array}{l}\text { Questionnaires: } \\
\text { Choir conductors }\end{array}$ & Other countries than South Africa \\
\hline $\begin{array}{l}\text { Questionnaires: } \\
\text { Composers }\end{array}$ & $\begin{array}{l}\text { South Africa: } \\
\text { Cape province: Cape Town (2), Heralds Bay } \\
\text { (1) } \\
\text { Gauteng: Pretoria (3), Johannesburg (1) }\end{array}$ & 7 \\
\hline
\end{tabular}

Note that some participants were involved in more than one research activity, e.g. questionnaire and interviews, or questionnaires and personal communication.

\section{Appendix C}

Table 4: Language medium of the various choirs of the participants

\begin{tabular}{|l|c|}
\hline $\begin{array}{l}\text { Language medium of the various choirs of the } \\
\text { participants }\end{array}$ & $\begin{array}{c}\text { Number of } \\
\text { respondents }\end{array}$ \\
\hline English & 26 \\
\hline Sepedi & 5 \\
\hline Afrikaans & 25 \\
\hline Other languages (Participants from abroad) & 7 \\
\hline
\end{tabular}

